ER

39,6

Received 24 April 2017 Revised 17 July 2017 Accepted 17 July 2017

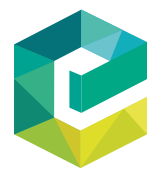

Employee Relations Vol. 39 No. 6, 2017 pp. $790-799$ Emerald Publishing Limited 0142-5455 DOI 10.1108/ER-04-2017-0095

\section{The UK living wage} A trade union perspective

\author{
Paul John Sellers \\ Economic and Social Affairs Department, Trades Union Congress, London, UK
}

\begin{abstract}
Purpose - The purpose of this paper is to explore the value that UK trade unions now place on the living wage.

Design/methodology/approach - The author is the TUC's Pay Policy Officer and examines the issue from a practitioner's perspective.

Findings - The living wage now has a well-established place within the hierarchy of pay demands adopted by UK trade unions. This continues a tradition of unions supporting norms and regulations as an adjunct to collective bargaining. However, support had to be achieved through a process of negotiation with the broader UK living wage campaign.

Practical implications - The paper concludes that there are good prospects for the living wage, and thus for the continued trade union support.

Social implications - The living wage standard is seen as having a strong moral basis, which often helps to win agreement with good employers. This results in a steady stream of workers out of in-work poverty. The credit for such pay increases is often shared between employers and trade unions.

Originality/value - The paper is written by a practitioner with inside knowledge and experience of the entire course of the living wage campaign in the UK and how it has been adopted and integrated by trade unions.
\end{abstract}

Keywords Collective bargaining, Trade union bargaining strategy, Trade unions and pay regulation, Trade unions and the living wage, UK living wage campaign and trade unions

Paper type Viewpoint

\section{Introduction}

The need for workers to earn a living wage has long been argued, both within the trade union movement and much wider. The concept is said to have been coined by Adam Smith and has been able to generate broad enough appeal to include Pope Leo XIII, Winston Churchill and Franklin Roosevelt as its advocates. It is now embedded in respected standards like the UN Declaration of Human Rights, whilst the European Social Charter expresses the concept as "all workers have the right to a fair remuneration sufficient for a decent standard of living for themselves and their families" (Council of Europe, 1996). It is widely understood as being the minimum income necessary for a worker to meet their basic needs. It would be hard for anybody to argue that such an aspiration should not be met, but there has been plenty of room to debate how the living wage should be operationalized.

This paper examines how the living wage has developed trade union support in the UK, set in the context of their pragmatic view of the interplay between free collective bargaining and state support for workers. It is argued that the TUC view of the living wage is analogous to the way in which UK unions have supported a number of statutory measures over the years. Second, the main focus is the development of the UK campaign during the last 16 years, which has arguably established a normative voluntary accredited standard for

\footnotetext{
(C) Paul Sellers. Published by Emerald Publishing Limited. This article is published under the Creative Commons Attribution (CC BY 4.0) licence. Anyone may reproduce, distribute, translate and create derivative works of this article (for both commercial and non-commercial purposes), subject to full attribution to the original publication and authors. The full terms of this licence may be seen at http://creativecommons.org/licences/by/4.0/legalcode
} 
employers who wish to be model employers. The UK Living Wage Foundation (2017) sets the rates and has so far accredited more than 3,000 living wage employers. Third, I also discuss briefly the strengths and weaknesses of the current campaign model, as viewed by trade unions, and set out some thoughts about the TUC fit into the Living Wage Foundation campaign in a political and economic climate where we are finding it increasingly hard to predict the future.

\section{Free collective bargaining and state support}

Trade unions in the UK have sometimes taken the view that negotiating wages should be exclusively the business of trade unions through free collective bargaining. When trade unions are in a strong position, then they are, quite rationally, more likely to want industrial relations to be unregulated whilst employers prefer regulation. However, if the position is reversed to some degree, then unions are more likely to press for supportive regulations and normative measures.

In the post-war period, there was a fair degree of consensus between the main political parties that collective bargaining was a good way of bringing order and fairness to the workplace. In such a climate, trade union membership in the UK grew quite strongly (Taylor, 2000). We should also note that even when unions where in their strongest position they have generally continued to support existing regulations and norms. Even during periods of strong union growth, there has been recognition that collective bargaining could not immediately deal with all the low pay and in-work poverty problems, so earlier gains were defended. For example, unions supported the Fair Wages Resolution from its introduction in 1891, until its abolition in 1983. This measure ensured that private companies undertaking work for the public sector had to pay fairly, which came to be interpreted as the collectively bargained rate (Fox, 1985, p. 246). Unions had also welcomed the creation of the Trade Boards in 1909, which set wages in low-paying industries and their expansion, as Wages Councils in 1945, which covered more than 2.5 million workers. We also opposed the abolition of the majority of these bodies in 1993, and still support the surviving boards, which continue to set agricultural wages in Scotland, Wales and Northern Ireland (Prowse and Fells, 2016a).

Yet there has sometimes been some tension between the TUC unions' desire to see everything done by stronger unions and collective bargaining and such regulatory measures. For example, our records reveal that the TUC's Joint Committee on the Living Wage (1927-1929) could not actually agree on any measures on wages themselves, but instead proposed that low wages be addressed by state help in the form of a family allowance paying a benefit to parents. This became a persistent TUC campaign that eventually led to this measure being introduced 16 years later (Taylor, 2000). In the same vein, UK trade unions used to argue against the introduction of a general statutory minimum wage, arguing that it would reduce the incentives to join a union. However, by 1985, unions reviewed their position. Under pressure from a hostile government bent on driving down wages in public services through marketization, the TUC unions came around to supporting a general minimum wage.

Within its remit, the UK's statutory minimum wage has been a success, but trade unions argue that the rates should be higher, with some also tending towards the view that the minimum wage should increase to become a genuine statutory living wage (TUC, 2016). This brief preamble reminds us that trade unions have sometimes been willing to change tactics as the times change, and that they have been pragmatic both in searching for opportunities to improve wages and in terms of what might be incorporated under the banner of a living wage campaign. 
ER

39,6

\section{The origins of the modern living wage campaign}

The story of the modern living wage campaign really starts in 2001. This was a year that saw the second Labour landslide election victory, and by November the opposition was trailing by 31 points. It was also a year when the national minimum wage (NMW) increased from $£ 3.70$ to $£ 4.10$ (10.8 per cent), but with the accompanying proviso that it would only increase by 10 pence (2.4 per cent) in the following year (Brown, 2009). There was spirit in the air that greater fairness was possible, but a significant number of trade unions and campaigners had a sense that change was happening too slowly and would not do enough to help people in poorer communities (Lawton and Pennycook, 2013).

This was the background to the year that the East London Community Organisation (TELCO) and the trade unions UNISON, TGWU (now Unite) and the GMB started the first living wage campaign (GMB, Unison and Unite, 2013). This campaign was launched just two years after the introduction of the UK statutory NMW, but seven years after the abolition of most of the Wages Councils. In the interim, real wages had fallen in some of the low-paying industries. Thus the rationale for TELCO's community-based campaign was simply that the NMW was not set high enough to provide a real living wage, and the aim was that employers should be put under pressure to do the right thing. The development of Canary Wharf in the 1990s meant that inequalities were thrown into a particularly sharp relief (Wills and Linneker, 2012). Low-paid cleaners were working in the same offices as highly paid staff in bank headquarters. Unions could see the clear campaigning and organising opportunity to East London's unions offered by the TELCO campaign (TELCO) had been convened by the Citizens Organising Foundation, and was later to broaden out to become Citizens UK (Wills and Linneker, 2012). TELCO had consulted both the TUC and individual unions before launching its campaign. TUC discussions included a number of meetings with the lead organiser with the campaign, to discuss what a living wage standard might look like. Unsurprisingly, support came first from unions working in East London and then gained broader traction in the succeeding years. Trade union enthusiasm for the campaign increased as it became clearer that the NMW would continue to develop fairly slowly, as the Government was going to continue to instruct the Low Pay Commission to look at what rate the economy could bear without any significant danger of causing job losses, not at how much workers needed to live on.

\section{The organising philosophy and trade unions}

In addition, the nascent campaign fitted well with the contemporary trade union philosophy. The organising model had been adopted up by a number of trade unions in the late 1990s. This social movement model was also central to citizens organising campaigns like TELCO who encouraged citizens to come together to try to improve their living and working conditions. The social movement model allowed professional organisers to concentrate on building up confidence, networks, leadership and campaigning capacity, with the aim of generating the power to solve their own problems. For trade unions, the alternative paradigm would be the "servicing model", in which trade union officials provide representation and bargaining as services to union members. Many trade unions were increasingly focusing on facilitating on the organising model, leading to the foundation of the TUC Organising Academy in 1998 and the common practice since then of dividing organising and servicing roles between two different groups of union officers (Heery et al., 2013). Against this background, unions saw campaigning for the living wage partly as an organising and recruitment tool.

\section{From the first campaign victories to a professional standard}

By 2002, a few employers were already signing up to the living wage, largely amongst the corporate headquarters based in Canary Wharf. The rationale appeared to be a mixture of 
stick and carrot, avoiding the frequent campaigns and demonstrations taking place outside bank headquarters, plus a fair degree of actually wanting to be better corporate citizens. In 2005, the Greater London Authority (GLA) established an official London Living Wage (LLW). This is not a compulsory rate like the NMW but a voluntary standard. However, the GLA immediately paid the LLW to its direct employees and started to negotiate with its contractors. Whilst this process was instigated by Ken Livingstone, it has been actively supported his successor Boris Johnson (Prowse and Fells, 2016b), and the current Mayor Sadiq Khan has continued this tradition. In the following years, trade unions played a key rose in campaigns that persuaded a number of London hospitals and universities to adopt the LLW. Furthermore, unions were prominent in campaigns that resulted in a patchwork of Labour Party-controlled urban local authorities adopting their own living wage, including Brighton, Glasgow, Manchester, Sheffield, Preston and York (The Fair Pay Network, 2010).

In 2011, the campaign sharply picked up the pace. Citizens UK launched the Living Wage Foundation, which accredited employers who pay the living wage. The TUC is itself accredited as a living wage employer, as are a number of trade unions. By then, nearly 20 local authorities had adopted living wages for their areas. This had led to a proliferation of different geographically specific local living wages. However, it became clear that the existence of a growing number of local rates was actively deterring some UK-wide employers from adopting the living wage. The Living Wage Foundation campaign then helped to establish a single living wage rate for employees across the whole UK outside London, which was successfully launched in November 2011. It was no mean feat to get agreement from existing living wages areas and well-established campaigns like the Scottish Poverty Alliance and the English-living wage cities, all of which had an existing trade union stake. It was also the point where the campaign started to become a widely accepted minimum standard for businesses.

\section{Negotiating trade unions' support}

The road to universal union support was not always straightforward and was the result of a long and gradual process of relationship building and negotiation. The post-2011 move towards establishing a business standard has not put an end to the more traditional campaign triumvirate of organising demonstrations, media campaigning and shareholder action. Nevertheless, it has helped to consolidate trade union support by diminishing the potential for accidently treading on each other's toes. One recurring source of tension was simply that campaigning for a living wage could sometimes be read as a criticism of hard-won collective bargaining agreements, making it unpopular with some union officers. Another source was that in the earlier stages of the campaign communication was an inconsistent on both sides, so there were occasionally unwanted surprises. These concerns are both present in the following anecdote:

One trade union officer complained to me that they had turned up at a London hospital to discuss the implementation of the 2004 NHS Agenda for Change the national pay agreement, which was the result a very complicated and long-winded negotiation process, only to find a living wage demo at the gates telling her members that "the union rates were not enough".

The context in which unions viewed the living wage was sharpening. Even before the last recession, trade union concerns about poor quality, precarious work were growing. The TUC (2007) established a Commission on Vulnerable Employment. In the following year, a key agreement was signed between the trade unions Unite, GMB and UCATT and the Olympic Development Agency. This was later extended to guarantee all workers involved in the Olympics the living wage. As this agreement is still regarded as a model of best practice this was a significant factor in helping to consolidate trade union support for 
ER

39,6

794

the living wage. At the 2010 TUC Congress, the general secretary spoke at an official fringe event in favour of adopting the living wage as a campaign target. This started a process that led to the living wage being a target in our Britain Needs A Pay Rise campaign (TUC, 2014).

Since 2011, both the TUC and the Living Wage Foundation were committed to improve communication by broadening and deepening our links. The TUC nominee joined the Living Wage Advisory Council when it was established, and the TUC does much of the liaison with unions. Most recently, in 2016 the LWF established a Living Wage Commission in order to provide better governance for the standard and to address some of the issues that were growing in importance as the living wage became more successful. Most notably, the LLW and the UK rate had been devised by two different bodies had two somewhat different methodologies and tended to move at quite different speeds. The TUC General Secretary Frances O'Grady sits on the Commission, which has successfully completed its first remit. This body will continue to meet once or twice a year to deal with governance issues. The Commission held successful sessions with a range of trade unions, to ensure that living wage would continue to thrive and increase in value. There have been some lively discussions within the TUC unions about the voluntary nature of the UK living wage. The TUC also has a target of raising the NMW to £10 an hour, which we are actively pursuing, with the General Council making a decision about our short-term target each year (TUC, 2014).

There has also been some debate about how the living wage links with collective bargaining. This has particularly been the case in the public sector where the government has set a 1 per cent cap on pay increases that looks set to continue until 2020. Against this backdrop, anything less than very careful handling of the living wage may create a zero-sum game in which lower paid workers get a pay rise at the expense of more senior staff on the pay rates just above. Nevertheless, the power of the living wage as an ideal and its usefulness to unions as a moral reference point in bargaining has generally entrenched support and has broadly been integrated with other union objectives.

\section{How do the TUC unions fit the real living wage into their strategies?}

Trade unions formally adopted the living wage as a target for our pay campaign at the 2011 TUC Congress. All the unions who represent low-paid workers now see the living wage as a useful standard that they can use in collective bargaining, as part of general pay claim. So, for example, a claim may call for something like "a 2 per cent increase, plus staff on the bottom grade will have their pay increased to the living wage". Alternatively, unions might use the living wage both as an organising tool, with a campaign goal to get a particular group of low-paid workers paid the living wage. A series of strikes by the Ritzy cinema workers in Brixton and their joint strike with Hackney Picturehouse workers (The Guardian, 2016) have been an example of the BECTU trade union using this approach.

The campaign for the living wage is now firmly rooted in the broad hierarchy of trade union demands, which might be understood as comprising the following pyramid of goals, all of which are set against the backdrop of wanting to build trade union organisation influence, whilst also trying to protect existing members from a negative race to the bottom on pay. First, to raise the statutory NMW as far as possible towards the $£ 10$ target and strongly enforce it. Second, to persuade employers to pay the living wage, which remains higher than the statutory minimum wage, wherever this can be achieved; and third, to negotiate a strong pay rise for the 80 per cent of union members who earn more than the living wage. Union campaigns to end the excesses in boardroom pay could be seen on the apex of the pay goals pyramid as it fits into TUC over-arching narrative that pay should be fairer. The emphasis varies for different unions. Retail is a difficult case. The shop workers union USDAW (2017) has achieved rates that are close to the living wage in many of their collective bargaining deals but no major unionised retail chain has yet adopted it. 
At the other end of the scale, professional unions representing medical professionals and teachers simply have no members paid below the living wage but are supportive of campaigns for living wages for cleaners in schools and hospitals. Understandably, the most interest comes from the large general unions like Unite, UNISON and the GMB, who have direct contact with a range of low-paid workers and achieve quite a wide range of bottom pay rates in their agreements (GMB, Unison and Unite, 2013). In addition, the rail union RMT campaigns for the living wage for its members who are cleaners, the Communications Workers Union campaigns for agency workers in the postal service and other groups, whilst arts unions like Equity (actors), and the aforementioned BECTU (theatre technicians) also campaigns for a living wage in their industry. In the latter case, they are battling against a strong tendency for employers to want work for no pay at all, through unpaid "internships" and bogus "volunteering". This list of unions is not exhaustive. All of these unions have had some successes in winning the living wage for their members. The idea of moving up to the living wage is understandably very popular and can be a strong recruiting tool. Unions also take part in the Living Wage Foundation's annual Living Wage Week, when the new rates are announced in November, using the occasion as a springboard both for further grass roots campaigning and for media work.

\section{The government's "National living wage"}

It is a truism that success often leads to replication, with new challenges for the originators. Mainstream politicians have tended to like the idea of a voluntary living wage, although the last Labour government worried privately whether it might detract from their successful NMW. However, the Labour mayor of London was an important figure in pushing the campaign forward and the Labour Party made commitments to support the further development a living wage in both its 2010 and 2015 election campaigns. Prime Minister Cameron also said that the living wage was "an idea whose time has come" at the world economic forum at Davos (Cameron, 2014). TUC (2014) ran a campaign Britain Needs a Pay Rise. At the time many commentators were still discussing bearing down on inflation, even though the inflation rate was already below the Bank of England's 2 per cent target and continuing to fall. Former Chancellor George Osborne made the following surprise announcement in his July 2015 budget stating:

Britain deserves a pay rise and Britain is getting a pay rise. I am today introducing a new

National Living Wage. We've set it to reach $£ 9$ an hour by 2020 (HM Treasury, 2015).

His adoption of our campaign language shocked the TUC, CBI, the Low Pay Commission and the Living Wage Foundation, none of whom had been consulted. Such an announcement was made possible because the Conservative government had pragmatically accepted the NMW and wanted to rebrand and develop this popular measure. They also wanted to implement changes to in-work benefits, which would have disadvantaged a considerable number of working people. Increasing the NMW would at least partly counter that effect, whilst shifting responsibility back onto employees. The new rate only applied to adults aged 25 and above. This annoyed unions, who were campaigning for equal treatment for younger workers (TUC, 2015).

\section{The "National Living Wage" threat to the "real living wage"}

Clearly the announcement of the higher statutory rate posed a tangible threat for the real living wage campaign. Political support from government was cut off, whilst the title of the government's new rate title "National Living Wage" caused confusion in the media. The TUC worked together with the Living Wage Foundation in order to differentiate the voluntary standard. The TUC agreed to describe our rate as the "real living wage" 
ER

39,6

796

as opposed to the government title. This campaign seems to have had a positive impact on media understanding, although hard-pressed journalists sometime still are confused.

Another obvious threat was that a rapidly rising statutory rate might erode the headroom for the real living wage. However, running economic predictions of the revised methodology agreed by the Living Wage Commission suggests that future rates are likely to broadly run parallel to the development of the government's "National Living Wage". Thus the "real living wage" has continued to thrive, increasing its affiliations by 50 per cent in 2016, the year after the government's national living wage was announced and doubling them in the past two years to reach over 3,000 accredited organisations by 2017 (Living Wage Foundation, 2017).

Unions continue to support the "real living wage" and to use it in their day-to-day bargaining, as it is seen as having the power of a moral standard (Padley et al., 2017). It is also a timely bargaining figure, which can be focused on profitable employers who can afford it. Unions in the public sector also commonly use the "Real living wage" as part of their pay claims. For example, trade union evidence to the NHS Pay Review body for 2017/2018 argues for restructuring pay bands 1-3 to pay the living wage and maintain pay differentials (Joint Negotiating and Consultative Committee Staff Side Evidence to the NHS Pay Review Body, 2017-2018). In a similar vein, the local government negotiated a claim in 2016 for deletion of NJC and all local pay points which fall below the level of the UK living wage (and deletion of Greater London Provincial Council pay points below London Living Wage) with a flat rate increase of $£ 1$ per hour on all other pay points (National Joint Council For Local Government Services, 2016).

In summary, the "real living wage" has survived the test posed by the introduction of the new government target. In addition (rather sadly), pressure has also been decreased as the government target rate to $£ 9$ has been downgraded. The $£ 9$ target was actually based on relating the NMW to 60 per cent of median earnings in 2020 (HM Treasury, 2015). Pay growth has been slower than expected and the target now seems more likely to yield around $£ 8.60$.

\section{Strengths and weaknesses of a voluntary living wage standard for trade unions and businesses}

In terms of advantages, businesses gain moral authority by paying a living wage and kudos for being good "citizens". They can also use the standard to differentiate themselves in the labour and product markets in a positive way. Unions can target bargaining efforts on employers with the ability to pay the real living wage, and those who might succumb to moral pressure, using traditional campaign methods like demonstrations. However, businesses that adopt the real living wage early get the strongest kudos. The effect is likely to erode as paying the "real living wage" becomes more widespread, although positive media responses are still quite strong at this point. For unions, some of the big employers have been hard to negotiate with as low pay has been a central part of their business model. It may be that a voluntary living wage strategy works best in the successful sectors and well-off regions. Voluntary living wage campaigns usually have less success in low pay areas, which means both sectors like bars and restaurants and the poorer parts of the UK. Similarly, it is the poorer US states who are still stuck with the 2009 federal minimum wage. Pursuit of a single rate can never be the only goal for trade unions, especially as the majority of their members already earn more, but it has been valued as a very useful measure.

One constraint is the government's determination to limit pay growth in the public sector, which was no doubt a factor in their decision to introduce their "National Living Wage". Lifting the public sector pay cap should be accompanied by a plan to ensure that the state always pays at least the real living wage. The government could then be in a position to return to proselyting in other sectors. Similarly, although many prominent businesses actively support the real living wage, business organisations 
like the $\mathrm{CBI}$ and the British Chamber of Commerce feel that they can say nothing without offending some of their members. Rather than the business organisations just marching at the pace of the slowest, they could do more to support their living wage members,

and those who actively want to pay more.

\section{Future prospects for the "real living wage"}

Those who try to predict long-term tend not to account for future obstacles so this section will only consider the next four to five years. It seems certain that the real living wage will continue to have moral authority and very likely that it will continue to have success. In these circumstances it is also very likely to continue to appeal to trade unions as a useful standard that can be used in recruitment and pay bargaining. One strong concern in recent years has been the rise of insecure work. The TUC's (2016) Living on the Edge report calculated that 3.2 million people were now engaged in agency work, casual work, and low-paid self-employment or were working on zero-hours contracts. One of the strengths of the living wage model is that it applies to agencies workers, contractors and casual workers, provided they work on the living wage employer's premises. It is not a panacea, as an hourly rate cannot fully compensate for short-time or irregular working, but it covers enough union concerns to be prescribed as part of the answer to low pay in the future. For economic conditions, it is impossible to predict the future days without considering the uncertainties that surround exit from the European Union. A key concern for the TUC is that workers must not pay the price for the decision to leave, and we lobby for a new deal that protects both jobs and rights, whilst managing migration better.

The initial impact, which has been to slow down economic growth and increase inflation, has had a rather negative effect on prospects for pay growth in general. However, the NMW has risen rapidly and, with inflation starting to turn up, it seems likely that trade unions will increase their focus on campaigning for the living wage. The rate of new accreditations to the Living Wage Foundation is holding up well. In the event of a severe downturn, which is an outcome that the TUC is actively working to avoid, some living wage employers may resign from the standard. However, we may take a fair degree of comfort from the fact that the Living Wage Foundation was launched at a time when the economy was unstable, yet there has been a rapid growth of business affiliations even though the economic recovery has been quite slow. It seems likely that most living wage employers would be slow to react to anything less serious than catastrophe, perhaps because to do so would risk damaging their brand identify and would send mixed messages to shareholders. It is also possible to envisage some positive scenarios where the labour market tightens post-Brexit, making it much more desirable for employers to differentiate by the living wage in order to attract and motivate their workers.

In summary, my conclusion is that the real living wage is not only certain to thrive while the economy is doing fairly well, but is also well enough entrenched to survive all but the most cataclysmic economic downturn. As long as the real living wage is quite successful, we can be sure that trade unions will continue to regard it as a useful standard, and will campaign and bargain for it to apply to more workers. The outcome is sure to benefit both low-paid workers and the trade unions that represent them.

\section{References}

Brown, W. (2009), "The process of fixing the British National Minimum Wage, 1997-2007", British Journal of Industrial Relations, Vol. 47 No. 2, pp. 429-443.

Fox, A. (1985), History and Heritage: The Social Origins of the British Industrial Relations System, Allen and Unwin, London. 
ER

39,6

Heery, E., Holgate, J. and Simms, M. (2013), Union Voices: Tactics and Tensions in UK Organising, Cornell University, London.

HM Treasury (2015), Policy Paper Summer Budget, HC264, House of Commons, London, 8 July.

Lawton, K. and Pennycook, M. (2013), "Beyond the bottom line: the challenges and opportunities of a living wage", Resolution Foundation/Institute for Public Policy Research, London, available at: www.resolutionfoundation.org/app/uploads/2014/08/Beyond_the_Bottom_Line_-_FINAL.pdf (accessed 3 May 2017).

Living Wage Foundation (2017), Who Pays the Living Wage?, Living Wage Foundation, London.

National Joint Council for Local Government Services (2016), “2016 and 2017 payscales and allowances", available at: www.unitetheunion.org/uploaded/documents/NJC $\% 20 \mathrm{Pay} \% 202016$ 1811-27961.pdf (accessed 3 May 2017).

NHS Joint Negotiating Staff Side Staff Side (2017-2018), "Evidence to the NHS Pay Review Body 2017-18", available at: www.unison.org.uk/content/uploads/2016/09/Staff-Side-PRB-evidence-2017-18_final_ 30-September.pdf (accessed 3 May 2017).

Padley, M., Davis, A., Hirsch, D., Horsley, N. and Valadez, L. (2017), "A minimum income standard for London 2016/17", Loughborough University/Trust for London Paper, Loughborough, available at: www.trustforlondon.org.uk/wp-content/uploads/2017/03/MIS_2016-17_Full_ Report.pdf (accessed 3 May 2017).

Prowse, P. and Fells, R. (2016a), "Living wage policy and practice”, Industrial Relations Journal, Vol. 47 No. 2, pp. 144-162.

Prowse, P. and Fells, R. (2016b), "The living wage in the UK - an analysis of the GMB campaign in local government", Labour and Industry, Vol. 26 No. 1, pp. 58-73.

Taylor, R. (2000), The TUC: From the General Strike to New Unionism, Palgrave MacMillan, London.

The Fair Pay Network (2010), "Unfinished business: the quest for a living wage”, available at: http:// slw.povertyalliance.org/userfiles/files/living-wage-rep-sep-2010.pdf (accessed 3 May 2017).

TUC (2007), "Hard work, hidden lives: the full report of the TUC Commission on vulnerable employment", TUC, available at: www.vulnerableworkers.org.uk/files/CoVE_full_report.pdf (accessed 3 May 2017).

TUC (2014), "Britain needs a pay rise", available at: www.tuc.org.uk/economic-issues/britain-needspay-rise/britain-needs-pay-rise-message-frances-ogrady (accessed 3 May 2017).

TUC (2015), "Minimum wage leaving younger workers behind warn TUC", available at: www.tuc.org. uk/economic-issues/labour-market/britain-needs-pay-rise/minimum-wage-leaving-youngerworkers-behind (accessed 3 May 2017).

TUC (2016), "Living on the edge", available at: www.tuc.org.uk/economic-issues/labour-market/livingedge (accessed 3 May 2017).

USDAW (2017), "A real living wage for all workers says USDAW”, available at: www.usdaw.org.uk/ About-Us/News/2017/May/A-real-living-wage-for-all-workers-says-Usdaw (accessed 3 May 2017).

Wills, J. and Linneker, B. (2012), "The costs and benefits of the London Living Wage", Trust for London/Queen Mary University report, London, available at: www.geog.qmul.ac.uk/livingwage/ pdf/Livingwagecostsandbenefits.pdf (accessed 3 May 2017).

\section{Further reading}

Cameron, D. (2014), "Speech to Davos Conference", available at: www.theguardian.com/business/2014/ jan/24/davos-2014-world-economic-forum-day-three-live (accessed 3 May 2017).

Clarke, S. and D’Arcy, C. (2016), Low Pay Britain, Resolution Foundation, London, available at: www. resolutionfoundation.org/app/uploads/2016/10/Low-Pay-Britain-2016.pdf

Council of Europe (1996), "European Social Charter (Revised)”, ETS 163, 3 May, Strasbourg, available at: www.refworld.org/docid/3ae6b3678.html (accessed 5 May 2017). 
GMB, Unison and Unite (2013), "Unions call for the lowest paid local government workers to be paid the living wage", available at: www.unison.org.uk/news/article/2013/11/unions-call-for-lowestpaid-local-government-workers-to-earn-the-living-wage/ (accessed 3 May 2017).

(The) Guardian (2016), "Ritzy and Picturehouse workers to strike over London living wage", 16 November, available at: www.theguardian.com/business/2016/nov/16/ritzy-andpicturehouse-cinema-workers-to-strike-over-london-living-wage (accessed 3 May 2017).

Heery, E., Hann, D. and Nash, D. (2015), “The living wage in Wales", available at: www.researchgate. net/publication/299845111_The_Living_Wage_in_Wales (accessed 3 May 2017).

Public Health England (2014), "Local action on health inequalities: health inequalities and the living wage", Health Equity Evidences Review 6, September, London, available at: www.gov. uk/government/uploads/system/uploads/attachment_data/file/357407/Review6_Living_ wage_health_inequalities.pdf (accessed 3 May 2017).

Unison (2016), "Bargaining for the living wage", available at: www.unison.org.uk/content/uploads/ 2016/12/Living-Wage.pdf (accessed 3 May 2017).

Unison/Unite/GMB (2013), "Winning a living wage for local government", available at: www. unitetheunion.org/uploaded/documents/LGLivingWageLeaflet11-13394.pdf (accessed 3 May 2017).

\section{About the author}

Paul John Sellers is the TUC's Pay Policy Officer. His role is to work with trade unions, government and opposition to promote better pay for working people. He was involved in living wage campaign from the start, having joined the TUC in 1998 after completing an MA Degree in Industrial Relations at the University of Warwick. His previous career included such diverse experiences as building powerboats, working as a courier, managing a supermarket and chairing the personnel committee of his local council. Paul John Sellers can be contacted at: psellers@tuc.org.uk

For instructions on how to order reprints of this article, please visit our website: 